\title{
WORK SAFETY MANAGEMENT APPLIED TO A LAB USED BY A JUNIOR COMPANY OF CHEMICAL ENGINEERING
}

\author{
Ana Caroline Baú \\ Federal Technological University of Paraná, Ponta Grossa, Brazil \\ E-mail: anacbau@gmail.com \\ Emy Sakakibara \\ Federal Technological University of Paraná, Ponta Grossa, Brazil \\ E-mail: emy_sak@hotmail.com \\ Fernanda Deschamps \\ Federal Technological University of Paraná, Ponta Grossa, Brazil \\ E-mail: feer.ps@hotmail.com \\ Letícia Coutinho Christóforo \\ Federal Technological University of Paraná, Ponta Grossa, Brazil \\ E-mail: le_christoforo@hotmail.com \\ Daiane Maria De Genaro Chiroli \\ Federal Technological University of Paraná, Ponta Grossa, Brazil \\ E-mail: daianechiroli@utfpr.edu.br \\ Submission: $15 / 02 / 2018$ \\ Revision: 15/03/2018 \\ Accept: 11/06/2018
}

\section{ABSTRACT}

This article aims at the implementation of safety at work in the daily life of a Junior Company, which often uses laboratories for chemical analysis. To achieve the objective, initially a risk map was structured. Then, a business model was defined, adding safety factors through the methodology of Business Model Canvas. And finally, the application of the Balanced Scorecard, proposing objectives and operation's indicators relating this specific junior company. When the analysis was done, the presence of hazards was detected in the laboratory and there have been set ways to eliminate or minimize these risks and accidents at work.

Therefore, after the implementation of this study, the company has a structured safety culture, allowing focused actions of improvements, education and training. 
Keywords: laboratory; work safety; risk map; canvas; balanced scorecard.

\section{INTRODUCTION}

In Brazil, in 1977, the consolidation of labor laws occurred, assigning rights and duties for employers and employees regarding safety standards and medical program. Labor safety, defined as a matter of great importance within labor relations, sets measures and actions that aim to better working conditions for employees, reducing the occurrence of accidents, which generate personal suffering, health system costs, utilization of the social security system, as well as production stoppage and the expense of defective machinery (IIDA, 2005). The security is important in all environments, whether it is the community, companies or educational environments.

In this context, biosecurity and biosafety refer to the use of knowledge, techniques and equipment, in order to prevent professional, academic, community, laboratory and the environment from the exposure of potentially pathogenic biological agents. For the purpose of establishing secure conditions for handling and containment of biological agents, including: safety equipment, techniques and laboratory practices, physical structure of laboratories, as well as administrative management (HIRATA; MACRAILD, 2002; BRAZIL, 2006; MASTROENI, 2005).

Education is a strong tool in the systematic construction and fields' promotion, knowledge and skills, as well as in creating desired attitudes towards issues of occupational safety and health (OSH), including environment, safety of technical equipment and optimization of working conditions (KOZÍK; BULLA, 2013).

Within the educational context, a Junior Company can be highlighted, since it is a civil non-profit social organization, with educational purposes, constituted and administered exclusively by undergraduate and graduate students of higher education, within their areas of training. The Company provides services to other enterprises, institutions and society, under the guidance of professors and professionals with the objective to consolidate and enhance the learning of its members.

Considering that this work was developed in the context of a Junior Company of the chemical engineering course, in a Brazilian federal University, which handles development and innovation projects, process' optimization and physic-chemical analysis and also being able to use biological laboratory, which allows greater 
INDEPENDENT JOURNAL OF MANAGEMENT \& PRODUCTION (IJM\&P)

http://www.ijmp.jor.br

v. 10, n. 1, January - February 2019

ISSN: 2236-269X

DOI: 10.14807/ijmp.v10i1.787

promotion of knowledge and practice research about business objectives (MOGOPODI; PAPHONE; PETROS, 2015). Laboratory classes are, therefore, considered an important part of the curriculum (WALTERS; LAWRENCE; JALSA, 2017).

When a laboratory is utilized, regardless the type of activity that takes place, several risks are present, such as biological, chemical or physical (FESZTEROVÁ, 2015; EMERY et al., 1998). However, where the present study was carried out, similarly to most universities, the level of laboratory safety rules was poor when compared to industries. This occurs most often due to limited personnel (BACKUS et al., 2011; MARENDAZ; SUARD; MEYER, 2013).

Generally, universities provide basic engineering controls to reduce the levels of exposure with risk control regarding safety and health at work (STEWARD; WILSON; WANG, 2015). Several authors (CHERN; LAY; WANG, 2003; SHYU, 1998; TSAY; SU; DOONG, 2000; STEWARD; WILSON; WANG, 2015; WUA; LIU; LU, 2007) report on accidents and the importance of inserting means to ensure greater safety in laboratories of universities. Laboratory personnel properly trained and well organized are fundamental to the successful operation of a research facility (EZZELLE et al., 2010), in this way ensuring a greater climate of safety in the workplace.

For safety in laboratory's activities, it is necessary to insert Personal Protective Equipment (PPE) and Collective Protective Equipment (CPE) that along with best laboratory practices aim at the protection of individuals and laboratories themselves (HIRATA; MACRAILD, 2002; BRAZIL, 2006; PENNA et al., 2010).

However, solely such equipment does not guarantee total protection, it is essential to know the risks inherent in this environment, in order to train people properly, and use the risk map's knowledge. The risk map is a descriptive and qualitative methodology for territorial risk research (HÖKERBERG et al., 2006).

Widespread in Brazil in the early 1980 and currently, the risk map is obligation of Internal Committee of Accident Prevention (CIPA) with the guidance of specialists in the Safety Engineering Service and Occupational Medicine (SESMT), standardized by the Brazilian Regulatory Standard No. 5, also known as NR-5. 
INDEPENDENT JOURNAL OF MANAGEMENT \& PRODUCTION (IJM\&P)

http://www.ijmp.jor.br

v. 10, n. 1, January - February 2019

ISSN: 2236-269X

DOI: 10.14807/ijmp.v10i1.787

The map is presented as a graphic form of accidents' risk in various workplaces, through proportional different color and size circles, indicating small, medium and large risks. (PONTE; RIBAS; PINTO, 2014). The different risks presented in the map are sorted according to the Brazilian Regulatory Standard No. 9 (NR-9) and the Brazilian Regulatory Standard No. 5 which inserted the need to include ergonomic risks and accidents (BARROS; SILVA; DE OLIVEIRA, 2016).

According to Orofino (2011), a company, in order to deal with the market front responses to its business model, needs to have the knowledge of how its business works, internally and externally. It is defined, with the knowledge of the company's employees, a business model according to the performance of the same, adding safety factors, through the methodology of the Business Model Canvas, described by Osterwalder and Pigneur (2011).

A business model is structured logically and provides information related to how the company creates, delivers and captures value. For the design of this model, among the elements that should be considered are value capture mechanisms, technologies and features to be incorporated in the product or service, benefit of the customers in using or consuming the product or service, identification of the target market segment, as well as the revenue stream available (TEECE, 2009).

In accordance with Osterwalder and Pigneur (2011), the Business Model Canvas is a tool, that uses a framework and promotes a common language to describe, evaluate and change a business model. Consists of nine basic components that cover four key areas of business: customers, supply, infrastructure and financial viability.

After defining the strategies of Junior Company and developing the risk map, the Balanced Scorecard has been applied. According to Kaplan and Norton (1997), I order to propose objectives and indicators of operating this Junior Company, the work safety sector and the visions of leaders in this company need to be considered.

The choice of the implementation of this tool is because it allows the observation of systemic organization, overall assessment of the performance of the company, better allocation of resources and creation of an organizational culture involving all corporation members aiming at compliance with all established goals, from a simple and easy-to-access document. 


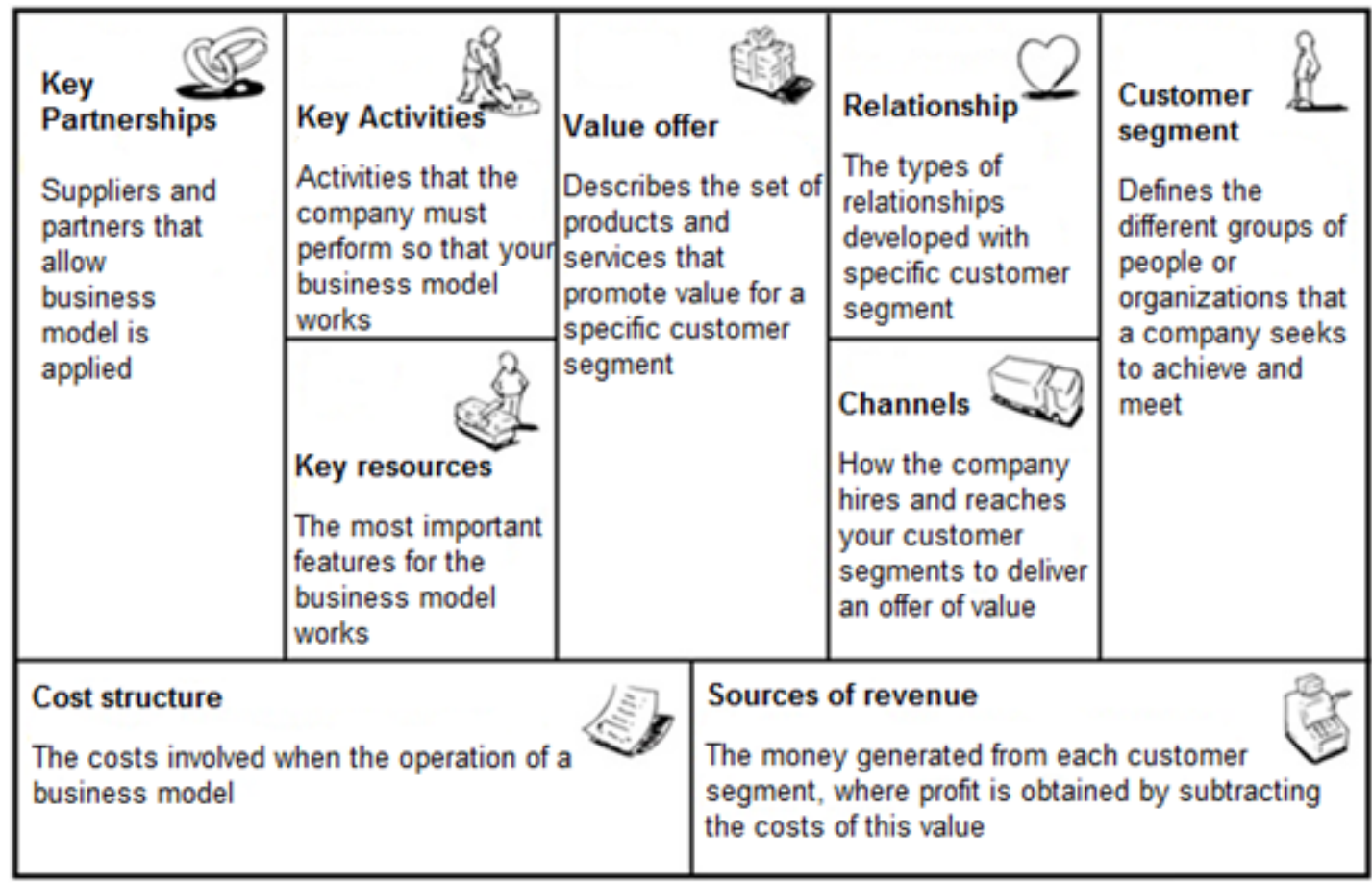

Figure 1: Business Model Canvas Composition

Thus, in conjunction with other methods, this article describes the application of multiple methodologies in the functioning of the company with the focus on work safety engineering.

According to Costa (2004), the Companies go through considerable difficulties during their strategy implementation process, since they utilize inadequate tools while measuring data, letting slide that the intangible data must be taken in account. Thereon, Kaplan e Norton (1997) developed an additional tool, the Balanced Scorecard.

The Balanced Scorecard (BSC), is presented by Kaplan and Norton (1997) as a tool that represents the companies' mission and strategy as a set of performance measures, which works as basis to a system of strategic measure and management.

This tool allows the measure of the company's performance under different perspectives: financial, customer point of view, internal processes, learning and growth. The company needs to develop tangible and intangible skills in matter of information capital, humane and organization in order to achieve improvement in the internal activities of value chain, thus improving the business processes (KAPLAN; NORTON, 2004; JORDÃO; NOVAS, 2013; SEN et al., 2017). 
INDEPENDENT JOURNAL OF MANAGEMENT \& PRODUCTION (IJM\&P)

http://www.ijmp.jor.br

v. 10, n. 1, January - February 2019

ISSN: 2236-269X

DOI: 10.14807/ijmp.v10i1.787

The scorecard creates a structure, a language, in order to transmit the mission and the strategy, generating an integrated board to track indicators and inform the employees about the vectors of present and future success, aligning the initiatives with the strategy, reaching cooperative development (BENTO et al., 2013; BRITO; BRITO, 2012; KAPLAN, 2010; SEN et al., 2017; YOSHIKUNI; ALBERTIN, 2014). The BSC is an operation based on the cause and effect of relationships between the components of organizational strategy (KAPLAN; NORTON, 2004).

According to Kaplan e Norton (1997), the BSC is more than a tactical or operation system, it is a strategic management system to administrate the strategy in long term. The four perspectives of the scorecard balance the short and long-term objectives, the desired results, the performance vectors of these results, the solid objective measurements and the imprecise ones, thus making it easier to align the company in order to execute a strategy with measurements that points to the same direction.

Taking into consideration, the objective of the present article is the implementation of safety in the daily work of a Junior Company that uses frequently laboratories to do chemical analysis, which can represent a bigger risk to the physical integrity of the collaborator, therefore being the focus of this study.

Considering everything mentioned above, to implement daily safety work in the Junior Company, the working systematic was defined, that is, a flow chart with the steps the company must follow to apply this proposition.

\section{METODOLOGY}

\subsection{Process' Flow Chart}

In general, work safety management during the execution of a project starts when the Junior Company receives the project and chooses the laboratory that will be used, until when the indicators are applied and the monitoring is at place, as figure 2 shows.

\begin{tabular}{|c|c|c|c|c|c|c|}
\hline $\begin{array}{l}\text { Project's } \\
\text { receivement }\end{array}$ & & $\begin{array}{l}\text { Risk Map } \\
\text { Elaboration }\end{array}$ & & $\begin{array}{c}\text { BSC } \\
\text { Elaboration }\end{array}$ & & $\begin{array}{l}\text { Constant } \\
\text { Monitoring }\end{array}$ \\
\hline • & 0 & 0 & $\bullet$ & 0 & ○ & - \\
\hline & $\begin{array}{l}\text { Laboratory } \\
\text { choosing }\end{array}$ & & $\begin{array}{c}\text { Canvas } \\
\text { Elaboration }\end{array}$ & & $\begin{array}{l}\text { Indicators } \\
\text { Appliance }\end{array}$ & \\
\hline
\end{tabular}

Figure 2: Safety management during the project's execution 
The first stage consists on receiving the customer's project and analyzing it in order to define the stages that must occur during its execution. Acknowledging theses stages, it is possible to choose the laboratory which owns the proper structure for the development. After choosing the laboratory and defining all the execution's details, the risk map, the Business Model Canvas and the BSC are elaborated accordingly with the following methodology. It is important to keep the application of the indicators chosen on the BSC in mind, and to keep monitoring.

\subsection{Risk Map methodology}

In order to develop the risk map, a verification of the work place was fulfilled, so it is possible to know the environment and identify the risks. Interviews with the collaborators of the Junior Company about the protection equipment, performed activities and accidents' risks are also taken in to account.

The risk map's elaboration, accordingly to the annex of the ordinance n. 25, of December 29th, 1994 occurs in stages, which are represented in board 1.

Board 1: Hazard Map elaboration

\begin{tabular}{|c|c|c|}
\hline Stages & Assignments & Actions \\
\hline \multirow{3}{*}{$\begin{array}{l}\text { Know the work } \\
\text { process of } \\
\text { designed place }\end{array}$} & Identify the workers & $\begin{array}{l}\text { Establish the number, gender and } \\
\text { age of the workers }\end{array}$ \\
\hline & Identify the work's tools and materials & $\begin{array}{l}\text { Go to the workplace and identify } \\
\text { all the equipment and materials }\end{array}$ \\
\hline & $\begin{array}{l}\text { Identify the performed activities and the } \\
\text { environment }\end{array}$ & $\begin{array}{l}\text { Know the performed activities } \\
\text { through visiting the place and } \\
\text { interviewing the workers }\end{array}$ \\
\hline $\begin{array}{l}\text { Identify the existing } \\
\text { risks }\end{array}$ & $\begin{array}{l}\text { Verify the existence of chemical, } \\
\text { physical, biological, ergonomic and } \\
\text { accident hazards }\end{array}$ & $\begin{array}{l}\text { Classify the main occupational } \\
\text { risks in groups, accordingly to its } \\
\text { origin }\end{array}$ \\
\hline $\begin{array}{l}\text { Establish the risk's } \\
\text { intensity }\end{array}$ & $\begin{array}{l}\text { Classify the hazard's intensity in low, } \\
\text { medium or high, in accord with its } \\
\text { meaning }\end{array}$ & $\begin{array}{l}\text { Classify the intensity of the risks } \\
\text { accordingly to the perception of } \\
\text { the workers }\end{array}$ \\
\hline \multirow{2}{*}{$\begin{array}{l}\text { Identify } \quad \text { preventive } \\
\text { measures }\end{array}$} & $\begin{array}{l}\text { Verify the collective and individual safety } \\
\text { measures }\end{array}$ & $\begin{array}{l}\text { Verify which measures protect the } \\
\text { health and physical integrity of the } \\
\text { worker }\end{array}$ \\
\hline & jork organizat & $\begin{array}{l}\text { Verify which work organization } \\
\text { measures are used at work }\end{array}$ \\
\hline $\begin{array}{l}\text { Identify the health } \\
\text { indicators }\end{array}$ & Verify & $\begin{array}{l}\text { Establish cause and frequency of } \\
\text { the occurred work accidents by } \\
\text { interviewing the workers }\end{array}$ \\
\hline $\begin{array}{l}\text { Hazard } \\
\text { elaboration }\end{array}$ & Elaborate the hazard map & $\begin{array}{l}\text { Elaborate the hazard map sketch } \\
\text { above the Company's layout }\end{array}$ \\
\hline
\end{tabular}


INDEPENDENT JOURNAL OF MANAGEMENT \& PRODUCTION (IJM\&P)

http://www.ijmp.jor.br

v. 10, n. 1, January - February 2019

ISSN: 2236-269X

DOI: 10.14807/ijmp.v10i1.787

According to the Brazilian Regulatory Standard No. 9 (NR-9), the chemical risks are substances, compounds or products that can penetrate the organism through the respiratory tract, in dust, smoke, mist, fog or steam form, or the ones that by its nature may have contact or be absorbed through the skin or by ingestion.

As stated by NR-9, physical risks are the various shapes of energy which the worker is exposed to, such as: noise, vibrations, abnormal pressures, extreme temperatures (heat and cold), ionizing and non-ionizing radiation, as well as ultrasound and infrasound. And the biological agents, according to NR-9, are the microorganisms, as well as, bacteria, fungi, bacilli, parasites, protozoan, virus, and others (BRASIL, 1994).

NR-5 describes the ergonomics risks, which can be any factor that interfere with the psycho-physiological characteristics of the worker, causing discomfort or affecting his health. The examples of ergonomics risks are: weight lifting, excessive work rhythm, monotony, repetitively, inadequate work posture, etc. And the accident risk is any factor that places the worker in a risky situation that can affect his wellbeing mental and physical, as well as his integrity. The following example are considered a risk of accident: unprotected machines and equipment, possibility of fire or explosion, lack of environment organization and inadequate storage.

After the classification of the risk, the risk map may be defined graphically by colors and circles on the layout of the workplace. The size of the circle represents the risk's degree. And the color indicates its type, as it is indicated on figure 3.

The low risks are the ones with concentration or intensity on a level that the damage to the collaborators may be considered negligible. The medium risks are defined when the conditions of the damaged agent are below the acceptable limits of the people, but still can cause discomfort, even if they use the collective or individual protection. Therefore, the high risks occur when the concentration, intensity, exposition time, etc. are above the limits that are considered acceptable by the human organism and there is no collective or individual protection that is effective. 


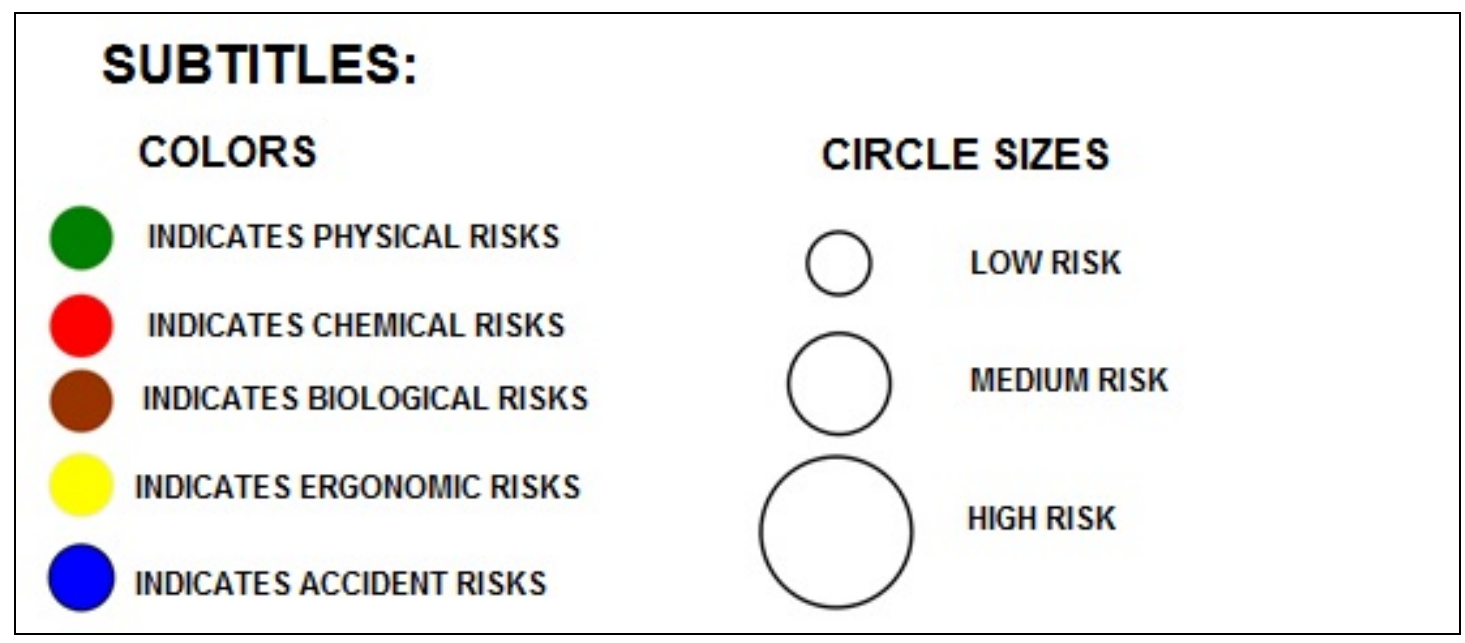

Figure 3: Hazard map subtitles

Fonte: SESTR (2013)

\subsection{Business Model Canvas methodology}

The figure 3 represents the way Canvas is applied to a company. Osterwalder and Pigneur (2011) allege that each of the nine components must be filled accordingly to the following methodology, disposed on the figure 1 .

- Customer Segment: In this component, the customer which have needs, behaviors or others common factors are grouped. If these factors are distinct, another customer segment is created. It's required to make conscient decision about which customers you ignore and which you must pay more attention.

- Value Offer: Definition of products and services, this component must represent the difference between your company and the others.

- Channels: Determination of the communication, distribution and sale channels that foment the Company-Customer interaction.

- Relationship: Clarification of the desired Company-Customer relationship, taking on account customers conquer, his loyalty as well as sales growth.

- Sources of revenue: Pricing mechanism proposed by the company, always keeping in mind the value that each customer segment is willing to pay.

- Key Resources: Definition of the resources that allow the company to achieve markets, keep relations and gain revenue.

- Key Activities: Define which actions are crucial to the success of the company's operation.

- Key Partnerships: Which alliances are needed in order to optimize the Business Model, to reduce the risks and to acquire resources. 
INDEPENDENT JOURNAL OF MANAGEMENT \& PRODUCTION (IJM\&P)

http://www.ijmp.jor.br

v. 10, n. 1, January - February 2019

ISSN: 2236-269X

DOI: 10.14807/ijmp.v10i1.787

- Cost Structure: Definition of the cost necessary to maintain the Business

Model and maintain the company.

\subsection{Balanced Scorecard methodology}

At first, it is fundamentally important to choose the sector of the company to perform the Balanced Scorecard, because when this methodology is applied in the whole company, it does not present significant results as when applied in sectors. Also, the company must select a leader for the scorecard, who will be responsible for the organization, philosophy, and methodology of the tool. The development will be executed by the high administration of the company.

To the construction of a Balanced Scorecard, according to Kaplan and Norton (1997), different steps are needed, which are present on chart 2.

Chart 2: BSC Methodology

\begin{tabular}{|c|c|c|}
\hline Steps & Tasks & Actions \\
\hline \multirow{2}{*}{$\begin{array}{l}\text { Definition } \\
\text { Indicators } \\
\text { Architecture }\end{array}$} & $\begin{array}{l}\text { Select the most appropriate } \\
\text { organizational unit }\end{array}$ & $\begin{array}{l}\text { To choose the unit, it must be analyzed in the } \\
\text { activities of a complete value chain that has a } \\
\text { strategy to accomplish its mission. }\end{array}$ \\
\hline & $\begin{array}{l}\text { Identify the relation between } \\
\text { the organizational unit and } \\
\text { the corporation }\end{array}$ & $\begin{array}{l}\text { The leader should conduct interviews with key } \\
\text { executives to learn about financial resources, core } \\
\text { business themes, and relationships with other units, } \\
\text { making their limitations visible. }\end{array}$ \\
\hline \multirow{3}{*}{$\begin{array}{l}\text { Consensus in } \\
\text { function of the } \\
\text { Strategic Objectives }\end{array}$} & $\begin{array}{l}\text { Conduct a first series of } \\
\text { interviews }\end{array}$ & $\begin{array}{l}\text { The leader prepares a basic scorecard material as } \\
\text { well as vision, mission, and strategy for the unit to } \\
\text { conduct the interviews with approximately } 10 \\
\text { executives, gaining insight into strategic goals and } \\
\text { preliminary ideas across the four perspectives. }\end{array}$ \\
\hline & Synthesis session & $\begin{array}{l}\text { From the results of the interviews, the leader must } \\
\text { make a list and a classification of objectives of the } \\
\text { four perspectives, prioritizing those that depict the } \\
\text { strategy of the unit. }\end{array}$ \\
\hline & Executive Workshop & $\begin{array}{l}\text { In the first workshop the leader should facilitate the } \\
\text { debate about the mission and strategy, showing the } \\
\text { objectives proposed in the interviews and their } \\
\text { classifications, selecting, with the high } \\
\text { administration group, three or four that are more } \\
\text { relevant. The leader must divide groups for each } \\
\text { chosen goal, and these are responsible for that } \\
\text { perspective. }\end{array}$ \\
\hline \multirow{2}{*}{$\begin{array}{lr}\text { Selection } & \text { and } \\
\text { Elaboration } & \text { of } \\
\text { Indicators } & \end{array}$} & Subgroups meeting & $\begin{array}{l}\text { The leader will work with individual subgroups to } \\
\text { refine strategic objectives, create indicators for } \\
\text { them, also create sources of information for } \\
\text { indicators and identify critical relationships between } \\
\text { indicators and perspectives. }\end{array}$ \\
\hline & Executive Workshop & $\begin{array}{l}\text { In this second workshop there should be a } \\
\text { discussion about the organization's vision, strategy, } \\
\text { objectives and experimental indicators for the } \\
\text { scorecard, starting to develop an implementation } \\
\text { plan and thinking of goals to overcome those } \\
\text { already outlined. }\end{array}$ \\
\hline
\end{tabular}


DOI: 10.14807/ijmp.v10i1.787

\begin{tabular}{|l|l|l|}
\hline \multirow{2}{*}{$\begin{array}{l}\text { Elaboration of the } \\
\text { Implementation Plan }\end{array}$} & $\begin{array}{l}\text { Develop the Implementation } \\
\text { Plan }\end{array}$ & $\begin{array}{l}\text { Team leaders must formalize overshooting goals } \\
\text { and develop an implementation plan for the } \\
\text { scorecard. }\end{array}$ \\
\cline { 2 - 4 } & $\begin{array}{l}\text { The third workshop aims to achieve at the final } \\
\text { decision on vision, objectives, and indicators } \\
\text { developed previously, validating the proposed } \\
\text { goals. }\end{array}$ \\
\cline { 2 - 4 } & $\begin{array}{l}\text { Conclude } \\
\text { Implementation Plan }\end{array}$ & $\begin{array}{l}\text { To create value, the scorecard must be integrated } \\
\text { with the organization's management system. }\end{array}$ \\
\hline
\end{tabular}

According to Kaplan and Norton, this methodology lasts approximately sixteen weeks to be implemented, and at the end of the project schedule, the executives and administrators of the organization should reach a consensus regarding the translation of the strategy into objectives and specific indicators for each perspective, which will be collected at every two weeks. Furthermore, they must understand the managerial processes that will undergo changes as a consequence of the implementation of the Balanced Scorecard.

\subsection{The company}

The Junior Company was founded in 2013 and works in the field of Chemical Engineering, focusing on development and innovation, process optimization and physical-chemical and biological analysis. The development of each project of this Junior Company is unique, where each employee present in the team directs all efforts to it, always being accompanied by a quality auditor, also responsible for ensuring the physical integrity of the employees. A Junior Company, unlike a Senior Company, operates within an Institution of Higher Education, constantly oriented by professors of its area.

\section{RESULTS AND DISCUSSION}

\section{1. $\quad$ Risks map}

The workplace has 65.5 square meters, with four central work benches and side benches with several equipment. This space only has an access door for employees entering and leaving, with a width of 1.60 meters and its opening is outside the workplace. Therefore, it follows the safety standard Brazilian Regulatory Standard No. 23, which states that the minimum width of the outlet openings should be 1.20 meters; and shall not open into the workplace. (COLARES; DE FREITAS, 2007). However, the passageway is not signaled by signs or light signals, indicating the direction of the exit, and there is no fire protection. 
The risks pointed out in this work environment are accidental, ergonomic, physical and chemical risks. Regarding the ergonomic risks, there was a predominance of incorrect postural conditions on the benches, which can cause discomfort. Accident's risks are predominant due to the disorganization of materials and their inadequate storage, also due to inadequate physical arrangement since a cabinet and shelf block the passage of employees.

The verified physical risk is due to noise produced by the mechanical agitator, orbital agitator, centrifuge), heat (heater plate and muffle) and radiation (photo catalysis equipment). The predominance of chemical risks, which, in turn, are related to direct contact with chemical products, and equipment such as the exhaust gas, rot evaporator, which release gases was also detected. Chemical products and reagents are stored on benches and in the chapel, so it also has a chemical risk of medium intensity. The risks were represented in the risk map according to figure 4 .

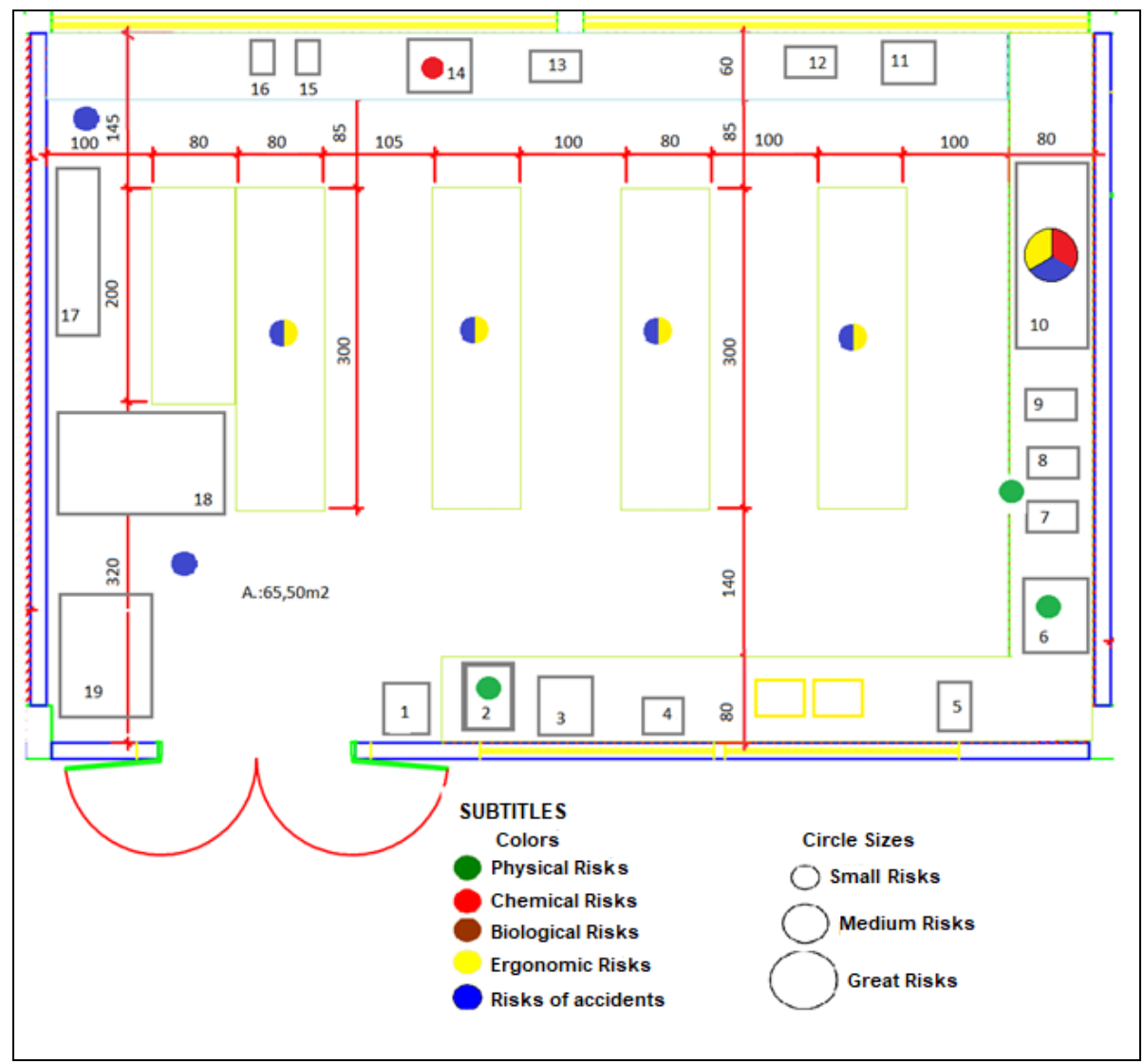

Figure 4: Risks Map

The chart 3 shows the equipment listed on figure 4 . 
Chart 3: List of Equipaments

\begin{tabular}{|l|l|l|l|}
\hline Number & Equipament & Number & Equipament \\
\hline 1 & Refrigerator & 11 & Orbital Shaker \\
\hline 2 & Centrifuge & 12 & Mecanic Shaker \\
\hline 3 & Gas Extractor & 13 & Microwave \\
\hline 4 & Thermostatic Bath & 14 & Rotoevaporator \\
\hline 5 & Destilator & 15 & Analytical Balance \\
\hline 6 & Muffle & 16 & Phmeter \\
\hline 7 & Heating Plate & 17 & Shelf \\
\hline 8 & Heating Plate & 18 & Wardrobe \\
\hline 9 & Metabolic Bath & $\mathbf{1 9}$ & Photocatalytic \\
\hline 10 & Exhaust hood & & \\
\hline
\end{tabular}

The Personal Protective Equipment (PPE) offered are hand protection, laboratory coat, safety goggles and dust mask according to Brazilian Regulatory Standard. These are used for handling chemicals and equipment manipulation. The chapel of exhaustion is the only Collective Protective Equipment (CPE) in the workplace. This equipment exhausts the gas and toxic vapor when the chemicals are being handled. In the chapel of exhaustion there is an ergonomic risk, chemical risk and risk of accident, because of the posture of the employees, existence of chemicals and lack of organization. The laboratory does not have emergency full body safety shower nor an emergency eye wash fountain.

Also, one of the main methods that can be used to minimize and avoid accidents or undesirable events concerns that were perceived are the correct use of PPE and CPE and the organization of the workplace.

\subsection{Business model canvas}

In order to obtain the Business Model Canvas of the Junior Company, the whole method of work of this company was analyzed, as well as its sectors and the progress of work safety as the projects are carried out. The two main focuses of this company, in the daily work, so that its employees act without concerns with their health and safety, are: proposal of constant application of the work safety in the projects and periodic or constant audits of work safety themselves. The figure 5 shows the Business Model Canvas obtained during this research. 


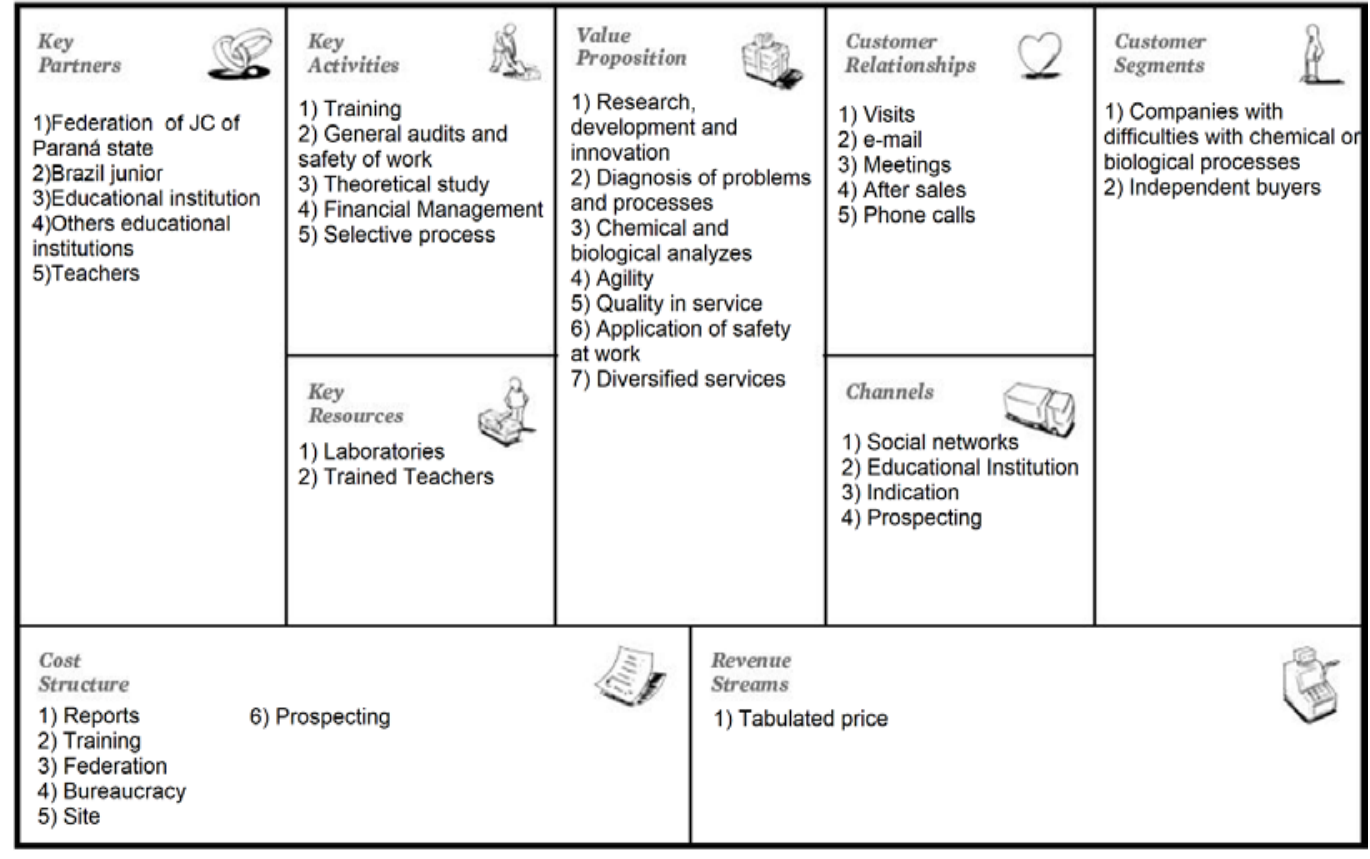

Figure 5: The Junior Company's Business Model Canvas

When performing a detailed analysis of the company's activities, it is noted that the Customer Segments mentioned in Canvas (figure 5) are the most frequent ones in the reality of the Junior Company. By having a difficulty in your process, or even the desire for improvement, any company can contact the employees of the Junior Company to obtain any of the Value Offers.

After this first contact, the Junior Company offers agility in the proposal of service and pricing through a previously developed chart, which considers the difficulties of the service, the potential of customer gain, the proportion of the customer, as well as the percentage needed to provision the expenses of its Cost Structure. Once the service is accepted and contracted by the customers, the Junior Company must prepare a team of trained employees who will handle the project, conducting a theoretical study with quality and safety auditors counting with the assistance of the professors of the Institution of Higher Education.

During the project development, there must be constant contact with the customer to ensure that their needs are being attended. By knowing that all these factors are being ensured, the Junior Company develops and perfects its business model. 


\subsection{Balanced Scorecard}

For the application of the Balanced Scorecard in the Junior Company in question, the managing director was chosen as the leader, who became responsible for the entire organization, philosophy, methodology and development of the Scorecard. The unit chosen for the implementation of this tool was the work safety sector of the company.

The organization counts on five directories besides the President, being: Project Management Directorate, which is in charge of the management of all the consultancies provided by the company; Quality Directorate that performs the internal audit of all processes, using tools such as risk map and Business Model Canvas, besides making mappings; Marketing Directorate that takes care of all the visual and sales of the company; Financial Legal Directorate is in charge of all the bureaucracies inherent in a company; and the Human Talents Directorate is responsible for looking after all employees and selecting new members for the organization.

For the development and implementation of this tool, managers were guided by the mission, vision and values of the company, which are:

- Mission: To promote solutions and innovations in chemical engineering, developing professionals capable of transforming society.

- Vision: To develop a complete professional.

- Values: Ethics, transparency, excellence, respect, leadership, empathy and professionalism.

The president of the junior company, in the position of leader, held interviews with the five directories of the company with the purpose of knowing the objectives for this specific unit in the four perspectives of the tool, all of them converged to have a greater safety in the laboratory activities carried out during the consultancies provided, having a greater control by the accidents occurred, aiming in the first place at the health and safety of the collaborator.

Among all the objectives listed, the leader ranked them in order of priority aiming the strategy of the unit, taking this list to the first executive workshop, managing, together with the directors to filter which would be the most appropriate to 
be implemented. The directors were divided into three subgroups and each one had a specific objective to create the indicators.

In the second executive workshop the strategic vision of the objectives and their indicators was discussed, possible objectives of overcoming and beginning of developing a plan of action for the implementation. The responsible of each subgroup developed with his team and documented the implementation plan and led to the discussion in the third executive workshop.

In the third workshop, the final discussion of the objectives and indicators was validated, validating all the proposals, and with the goals of overcoming, five objectives and six indicators were aggregated. The results obtained with the implementation of the Balanced Scorecard in the Junior Company are represented in Chart 4.

Chart 4: Objectives and Indicators.

\begin{tabular}{|l|l|}
\hline Objectives & Indicators \\
\hline Ensure employee health during project execution; & Number of accidents occurred per project carried out; \\
\hline $\begin{array}{l}\text { Ensure that there is no work accident involving } \\
\text { injured persons, damaged materials and wasted } \\
\text { time; }\end{array}$ & Number of employees injured per project carried out; \\
\hline $\begin{array}{l}\text { Ensure that there is no chemical or biological } \\
\text { contamination in the workplace; }\end{array}$ & $\begin{array}{l}\text { Number of cases of contamination (chemical or } \\
\text { biological) occurring per semester; }\end{array}$ \\
\hline Certify the correct use of PPE and CPE; & $\begin{array}{l}\text { Number of accident cases resulting from the misuse (or } \\
\text { non-use) of PPE and CPE per project carried out; }\end{array}$ \\
\hline $\begin{array}{l}\text { Ensure the quality of operation and stock of raw } \\
\text { materials and equipment. }\end{array}$ & Frequency at which equipment failed; \\
\cline { 2 - 3 } & Frequency of equipment maintenance and inventory. \\
\hline
\end{tabular}

The plan of action for the implementation of the scorecard was developed following the ensuing precepts:

- Inform the results obtained from the scorecard for all company employees;

- Training a team to collect information and prepare the indicators to certify that the objectives were achieved;

- Integration of these actions into the organizational culture of the company.

\section{CONCLUSION}

At the university where the present study was conducted, laboratories are used by all engineering courses, not only by the chemical engineering course or by the junior company. Due to the large number of people using these laboratories, it is necessary to develop safety principles and strategies in order to minimize or mitigate the existing risks. 
With the application of the three tools (Business Model Canvas, Risk Map and Balanced Scorecard) it was concluded that it was possible to identify the risks in the laboratory. With the risk map, it was verified that ergonomic, physical and chemical risks can be prevented or at least minimized by taking some actions, such as the correct use of PPE and CPE, signalization and organization of the workplace.

Business Model Canvas brought the systemic reality of the company, showing that the risks to the health of the employees occur in the period in which business consulting is happening, when employees spend a lot of time in laboratories to carry out the necessary analysis. This Junior Company had an unstructured work safety proposal, conducting periodic audits to ensure this matter.

With the structuring of the BSC it was possible to develop safety strategies in the laboratory, and with the implementation of the BSC the Junior Company started to have a well-structured culture of work safety in goals and indicators, and these are collected every two weeks.

This article comes to contribute with junior and senior companies that intend to improve the safety sector through the BSC methodology, leaving in a more explicit way the implementation of the same, thus promoting greater health and safety in the work of all employees of the company organization. Indicator targets have not been defined because as there are no historical records to date, after the practice, in the next semester, or according to the identifications, these will be defined.

All these joint actions will also enable an education and training program to be developed, since, for effective safety, it is essential that all laboratory users are adequately informed about safety principles and able to put them into practice in order to keep the environment safe.

\section{REFERENCES}

BACKUS, B.; FIVIZZANI, K.; GOODWIN, T.; FINSTER, D.; AUSTIN, E.; DOUB, W.; WIEDIGER, S.; KINSLEY, S. (2011) Laboratory safety culture: Summary of the chemical education research and practice - Safety in chemistry education panel discussion at the 46th Midwest and 39th Great Lakes Joint Regional American Chemical Society Meeting. St. Louis, Missouri, on October 21, 2011, J. Chem. Health Saf. 2012, p. 20-24

BRASIL.(2006) Biossegurança em laboratórios biomédicos e de microbiologia. Ministério da Saúde. Secretaria de Vigilância em Saúde. Departamento de Vigilância Epidemiológica. 3.ed. Brasília: Ministério da Saúde. 290p. 
BRASIL.(1978) Portaria MTB no 3.214, de 08 de Junho de 1978. Aprova as Normas Regulamentadoras - NR - do Capítulo V, Título II, da Consolidação das Leis do Trabalho, relativas a Segurança e Medicina do Trabalho. Diário Oficial da União, 06 de julho de 1978. Avaliable:

http://portal.mte.gov.br/data/files/8A7C816A33EF45990134335D0C415AD6/NR06\%20(atualizada)\%202011.pdf>. Access:15/12/2017.

BRASIL. (1994) Portaria No 25, de 29.12.94, do Secretário de Segurança e Saúde no Trabalho: Norma Regulamentadora - NR - 9. Brasília, DF: Câmara dos Deputados, Edições Câmara, 1994.

BARROS, I. F.; SILVA, L. R.; DE OLIVEIRA, J. L. (2016) Elaboração do mapa de risco na construção civil: um estudo de caso no canteiro de obras localizado na cidade de Quixadá. XXXVI ENCONTRO NACIONAL DE ENGENHARIA DE PRODUCÃO. 2016, João Pessoa. Anais... João Pessoa: ENEGEP, 2016.

BENTO, A.; BENTO, R.; WHITE, L. F. (2013) Validating cause-and-effect relationships in the balanced scorecard. Academy of Accounting and Financial Studies Journal, v. 17, n. 3, p. 45-55.

BRITO, R. P. DE.; BRITO, L. A. L. (2012) Vantagem competitiva, criação de valor e seus efeitos sobre o desempenho. RAE-Revista de Administração de Empresas, v. 52 , n. 1, p. 70-84.

COLARES, L. G. T.; DE FREITAS, C. M. (2007) Processo de trabalho e saúde de trabalhadores de uma unidade de alimentação e nutrição: entre a prescrição e o real do trabalho Work process and workers' health in a food and nutrition unit: prescribed versus actual work. Cad. Saúde Pública, v. 23, n. 12, p. 3011-3020.

CHERN, J. -Y.; LAY, C. -J.; WANG, D. -S. (2003) Report for supervising safety and health management in laboratories in technical schools and colleges in Taiwan (III). Taipei: Ministry of Education.

COSTA, B. S. R. (2004) O Balanced Scorecard em Xeque? Análise das suas limitações e propostas de novas interações através de um estudo de caso em uma indústria automobilística brasileira. Dissertation (Master in Production Engineering). Universidade Federal do Rio de Janeiro, Rio de Janeiro.

EMERY, R.; DELCLOS, G.; COOPER, S. P.; HARDY, R. (1998) Evaluating the relative status of health $\&$ safety programs for minority academic and research institution. Am. Ind. Hyg. Assoc. J., v. 59, n. 12, p. 882-888

EZZELLE, J.; RODRIGUEZ-CHAVEZ, I. R.; DARDEN, J. M. (2008) Guidelines on Good Clinical Laboratory Practice: Bridging Operations between Research and Clinical Research Laboratories. Journal of pharmaceutical and biomedical analysis, v. 46, n. 1, p. 18-29. doi:10.1016/j.jpba.2007.10.010.

FESZTEROVÁ, M. (2015) Education for Future Teachers to OHS Principles - Safety in Chemical Laboratory. Procedia - Social and Behavioral Sciences, n. 191, p. 890895.

HIRATA, M. H.; MANCINI FILHO, J. B.(2002) Manual de biossegurança. Barueri, SP: Manole. 495p.

HÖKERBERG, Yara Hahr Marques; et al. (2006) O processo de construção de mapas de risco em um hospital público. Cien Saude Colet, v. 11, n. 2, p. 503-513. 
IIDA, I. (2005) Ergonomia: projeto e produção. 2.ed. São Paulo: Edgard Blucher. 360p.

JORDÃO, R. V. D.; NOVAS, J. L. C. (2013) A study on the use of the balanced scorecard for strategy implementation in a large Brazilian mixed economy company. Journal of Technology Management \& Innovation, v. 8, n. 3, p.98-107.

KAPLAN, R. (2010) Conceptual foundations of the balanced scorecard [Working Paper № 10-074]. Harvard Business School Accounting \& Management Unit, Boston, USA.

KAPLAN, R. S.; NORTON, D. P. (1997) A estratégia em ação: balanced scorecard. Gulf Professional Publishing.

KOZÍK,T.; LUKÁČOVÁ, D. (2010) Bezpečnost' a ochrana zdravia pri práci súčast' univerzitného štúdia. In Cywilizacyjne wyzwania edukacji zawodowej: wybrane problemy wspólczesnej edukacji zawodowej w Polsce i na Slowacji (p. 5356). Rzeszow : Max Druk - Drukarnia Medyczna, ISBN 978-83-61483-76-2.

MARENDAZ, J. L.; SUARD, J. C.; MEYER, T. (2012) A systematic tool for assessment and classification of hazards in laboratories (ACHiL) Saf Sci. y. 2013, n. 53, p. 168-176. doi: 10.1016/j.ssci.2012.10.001. Avaliable:

http://www.sciencedirect.com/science/article/pii/S0925753512002342?via\%3Dihub

MOGOPODI, D.; PAPHANE, B.; PETROS, S. (2015) Assessment of chemical management practices and safety in junior secondary school laboratories in Gaborone. Journal of Chemical Health and Safety, v, 22, n. 5, p. 17-27.

OROFINO, M. A. R. (2011) Técnicas de criação do conhecimento no desenvolvimento de modelos de negócio. 233 Dissertation (Master in Engineering and Knowledge management). Universidade Federal de Santa Catarina. 2011.

OSTERWALDER, A.; PIGNEUR, Y. (2011) Business Model Generation inovação em modelos de negócios: um manual para visionários, inovadores e revolucionários. Alta Books.

PENNA, P. M. M. (2010) Biossegurança: uma revisão. Arquivos do Instituto Biológico, v. 77, n. 3, p. 555-465. Avaliable:

https://doi.org/10.1016/j.jchas.2015.01.001. In: http://www.sciencedirect.com/science/article/pii/S187155321500002X

PONTE, A. S.; RIBAS, M. A. M.; PINTO, V. M. (2014) A importância do mapa de risco para a prevenção de acidentes de trabalho em cozinhas/copas de hospitais do interior do Rio Grande do Sul/RS. Saúde (Santa Maria), p. 123-130.

SEN, D.; BINGOL, S.; VAYVAY, O. (2017) Strategic enterprise management for innovative companies: The last decade of the balanced scorecard. International Journal of Asian Social Science, v. 7, n. 1, p. 97-109.

SHYU, G. -G. (1998) Illegal safety and health in labs in colleges. United Daily News, October 7, 1998, 6th.

Steward, J. E.; Wilson, V. L.; Wang, W.-H. (2015) Evaluation of safety climate at a major public university. Division of Chemical Health and Safety of the American Chemical Society. p. 1871-5532. 
TEECE, D. J. (2009) Dynamic capabilities \& strategic management. Oxford: Oxford University Press.

THE INTERNATIONAL ORGANIZATION FOR STANDARDIZATION. (2009) ISO 31000: risk management-principles and guidelines: The International Organization for Standardization 2009 Contract No.: ISO 31000:2009(E).

TSAY, P. -J.; SU, H. -J.; DOONG, Y. -H. (2000) Sustainable management in campus circumstances: Measurement and improvement strategies of safety and health in universities and colleges in Taiwan. Journal of Environment Education, n. 44, p. $18-29$.

WU, T.; LIU, C.; LU, M. (2007) Safety climate in university and college laboratories: Impact of organizational and individual factors. J. Saf. Res., v. 8, n. 1, p. 91-102.

WALTERS, A. U. C.; LAWRENCE, W.; JALSA; N. K. (2017) Chemical laboratory safety awareness, attitudes and practices of tertiary students. Safety Science, n. 96, p. 161-171.

YOSHIKUNI, A. C.; ALBERTIN, A. L. (2014) Model analysis of the relationship between strategic organization knowledge and the use of information systems in firm performance in Brazil. Chinese Business Review, v. 13, n. 5, p. 301-319. 